\title{
Surface Renewable Hydrogen Ion-Selective Polymeric Composite Electrode Containing Iridium Oxide
}

\author{
Hongmei Quan, Won Kim, Koo-Chun Chung, and Jongman Park* \\ Department of Chemistry, Konkuk University, Seoul 143-701, Korea. *E-mail: jmpark@konkuk.ac.kr \\ Received April 6, 2005
}

\begin{abstract}
A surface renewable $\mathrm{pH}$ electrode was prepared by utilizing composite electrode technique. Iridium oxide micro-fine particles was prepared by hydrolysis of $\left(\mathrm{NH}_{4}\right)_{2} \mathrm{IrCl}_{6}$ at elevated temperature. The iridium oxide particles were mixed with well-dispersed carbon black and then filtered. The mixture was suspended in DMF containing PVC as a binder. The mixture was precipitated rapidly by adding large amount of water. The precipitate was ground and pressure-molded to iridium oxide composite electrode material. The electrode showed linear response between $\mathrm{pH} 1-13$ with 50 to $60 \mathrm{mV} / \mathrm{pH}$ slope. The electrode maintained the $\mathrm{pH}$ response without appreciable slope drift for 170 days if stored in deionized water. The electrode surface can be renewed reproducibly by simple grinding process whenever contaminated or deactivated.
\end{abstract}

Key Words : Hydrogen ion selective electrode, Composite electrode, Iridium oxide

\section{Introduction}

Despite of distinctive performance in wide range of applications of the glass membrane $\mathrm{pH}$ electrode the drawbacks are fragility, easy of fouling and lack of surface renewability especially in long-term measurements such as water quality monitoring systems. Polymeric membrane ionselective electrodes show similar problems except the fragility. They are not fragile but easy to be torn. One of the approaches for the improvement of ruggedness of $\mathrm{pH}$ electrode is the utilization of metal oxides such as $\mathrm{TiO}_{2}$, $\mathrm{RuO}_{2}, \mathrm{RhO}_{2}, \mathrm{SnO}_{2}, \mathrm{Ta}_{2} \mathrm{O}_{5}, \mathrm{OsO}_{2}, \mathrm{PtO}_{2}$ or $\mathrm{IrO}_{2} \cdot{ }^{1,2} \mathrm{pH}$ sensing electrodes based on the metal oxides are prepared by thermal or electrochemical deposition of oxide films on the surface of their mother metals or conducting inert metals. They are mostly inert and rugged in harsh applications. Nevertheless surface renewable $\mathrm{pH}$ electrode is desired for on-line monitoring systems like telemetric water quality monitoring systems where anti-fouling of the sensing elements is critical.

Among the metal oxide-based $\mathrm{pH}$ electrodes iridium oxide-based $\mathrm{pH}$ electrode has been extensively studied because of its outstanding behavior among the metal oxides. Thermally prepared iridium oxide-based $\mathrm{pH}$ electrodes shows quite close value of $59 \mathrm{mV} / \mathrm{pH}$ unit according to the following one electron reaction schemes. ${ }^{3,4}$

$$
\begin{gathered}
\mathrm{IrO}_{2}+\mathrm{H}^{+}+\mathrm{e}^{-} \rightarrow \mathrm{IrO} \cdot \mathrm{OH} \\
2 \mathrm{IrO}_{2}+2 \mathrm{H}^{+}+2 \mathrm{e}^{-} \rightarrow \mathrm{Ir}_{2} \mathrm{O}_{3}+\mathrm{H}_{2} \mathrm{O}
\end{gathered}
$$

Recently a micro-sized iridium oxide thin film electrode was prepared by sputtering technique for $\mathrm{pH}$ sensing in brain tissue or blood. ${ }^{5}$ A thick film $\mathrm{IrO}_{2}$-based $\mathrm{pH}$ electrode on the surface of Ir metal lasting 2.5 years with high stability was developed by carbonate melt oxidation technique. ${ }^{6}$ Carbon fiber was also used as a substrate instead of metallic Pt or Ir in the preparation of micro $\mathrm{pH}$ sensing electrode. ${ }^{7}$ Iridium oxide was deposited by electrochemical oxidation of $\mathrm{Na}_{3} \mathrm{IrCl}_{6}$ in $\mathrm{HCl}$ solution. It suggests other inactive conductors such as graphite or carbon black can be utilized as substrates of $\mathrm{IrO}_{2}$-based $\mathrm{pH}$ sensing electrodes. In this work polymeric modified-carbon composite electrode technique was examined for the preparation of surface renewable $\mathrm{pH}$ sensing electrode based $\mathrm{IrO}_{2}$. Polymeric carbon composite electrode can be modified with $\mathrm{IrO}_{2}$ micro-particles to get $\mathrm{pH}$ sensitivity as well as surface renewability. The surface of the composite electrode can be renewed easily by simple polishing or grinding whenever contaminated or deactivated. ${ }^{8,9}$ The followings are about their preparations and analytical characteristics.

\section{Experimental Section}

Reagents and instruments. All chemicals were reagent grade and used as received unless otherwise mentioned. Ammonium hexachloroiridate(IV) and polyvinyl chloride were from Aldrich. Ketjen black 600JD (semigraphitic carbon from Akzo Chemie) was ground well with a mortar and pestle after drying, and then stored in a sealed bottle. Aqueous solutions were prepared with deionized water (18 $\mathrm{M} \Omega$ ). In most cases commercial $\mathrm{pH}$ buffer solutions having $\mathrm{pH}=4,7$ and 10 were used for the calibration of $\mathrm{pH}$ meter. Otherwise home-made standard buffer solutions were prepared according to the recommended procedures.[10] Tris buffer $(0.1 \mathrm{M})$ was prepared for interference experiments. Electrode potentials were measured versus $\mathrm{Ag} / \mathrm{AgCl}$ reference electrode $(3 \mathrm{M} \mathrm{KCl})$ using a $\mathrm{pH}$ meter (Accumet 50 from Fisher Scientifics) at $22{ }^{\circ} \mathrm{C}$.

Electrode preparation. Micro-fine particles of $\mathrm{IrO}_{2}$ (possibly $\mathrm{IrO}_{2} \cdot \mathrm{xH}_{2} \mathrm{O}$ ) were prepared by the hydrolysis of hexachloroiridate at elevated temperature. ${ }^{11}$ An appropriate portion of $\left(\mathrm{NH}_{4}\right)_{2} \mathrm{IrCl}_{6}$ was dissolved in $150 \mathrm{~mL}$ of deionized water. The $\mathrm{pH}$ of resulting reddish brown solution was adjusted to about 8.2 with $0.25 \mathrm{M} \mathrm{NaOH}$ and followed by 
heating to $95{ }^{\circ} \mathrm{C}$ with constant stirring for 30 min under reflux setting in an oil bath. The solution turned to deep blue suspension. For the completion of hydrolysis of iridium complex the solution was cooled down to room temperature, and then the $\mathrm{pH}$ was adjusted to the initial $\mathrm{pH}$ with $\mathrm{NaOH}$. The processes of $\mathrm{pH}$ adjustment and heating were repeated until the $\mathrm{pH}$ stabilized to initial $\mathrm{pH}$ for the completion of the reaction. The solution was purged with oxygen at $95{ }^{\circ} \mathrm{C}$ for two hours with a setting of reflux condenser. The suspension of the hydrolytic product was cooled to room temperature. Well ground carbon black was added to the suspension with vigorous stirring. The mixture was sonicated frequently to disperse carbon black completely. Addition of small amount of ethanol was helpful for better dispersion of carbon black. The mixture was stirred overnight. The solid portion of the mixture was separated by filtration and dried under vacuum at $100{ }^{\circ} \mathrm{C}$ for 4 hours and followed by calcination at $200{ }^{\circ} \mathrm{C}$ for several hours under gentle flow of $\mathrm{Ar}$ to get $\mathrm{IrO}_{2} /$ carbon black mixture.

The $\mathrm{IrO}_{2} /$ carbon black mixture were added to $\mathrm{PVC}$ solution in $30 \mathrm{~mL}$ of DMF then mixed thoroughly by stirring vigorously overnight. Sudden addition of large amount deionized water to the mixture separated the solid components from DMF. The solid mixture was washed thoroughly with deionized water then dried at $70{ }^{\circ} \mathrm{C}$ overnight. The mixture was pressure molded into $\mathrm{IrO}_{2}$-modified polymeric composite electrode material at $100^{\circ} \mathrm{C}$. The electrode material was fabricated into electrodes for $\mathrm{pH}$ measurements. The surface of the electrode was ground using 2000 grit $\mathrm{SiC}$ emery paper. The electrodes were presoaked in $\mathrm{pH} 7$ buffer solution for 12 hours prior to use.

\section{Results and Discussion}

It has been known that the $\mathrm{pH}$ response of the iridium oxide-based electrodes depends on the preparation methods. Iridium oxides prepared by thermal oxidation or sputtering techniques are predominantly anhydrous oxides showing 59 $\mathrm{mV} / \mathrm{pH}$ unit according to the reaction (1) or (2). In contrast it is known that electrochemically prepared oxides are predominantly hydrated iridium oxides such as $\mathrm{IrO}_{2} \cdot 4 \mathrm{H}_{2} \mathrm{O}$, $\operatorname{Ir}(\mathrm{OH})_{4} \cdot 2 \mathrm{H}_{2} \mathrm{O},\left\{\mathrm{IrO}_{2}(\mathrm{OH})_{2} \cdot 2 \mathrm{H}_{2} \mathrm{O}\right\}^{2-} \cdot 2 \mathrm{H}^{+}$and show superNerntian response of about $90 \mathrm{mV} / \mathrm{pH}$ unit. ${ }^{12,13}$ The iridium oxide in this work was prepared by wet chemistry followed by low temperature calcination at $200{ }^{\circ} \mathrm{C}$. So it is not clear whether it corresponds to thermal oxidation product or not. Nevertheless the $\mathrm{pH}$ responses of the iridium oxide composite electrodes ranged from 50 to $60 \mathrm{mV} / \mathrm{pH}$ unit depending on the batch prepared as shown in Figure 1. They are quite close to the ideal value of $59 \mathrm{mV} / \mathrm{pH}$ unit. Initial conditioning of the electrode in $\mathrm{pH} 7$ buffer solution for prolonged period improved the $\mathrm{pH}$ response characteristics probably due to the rearrangement of the freshly produced oxide surface by solvation. It has been known that the electrodes prepared by sputtering or thermal oxidation techniques exhibit an aging effect showing negative drift of the electrode potential with time owing to the hydration of

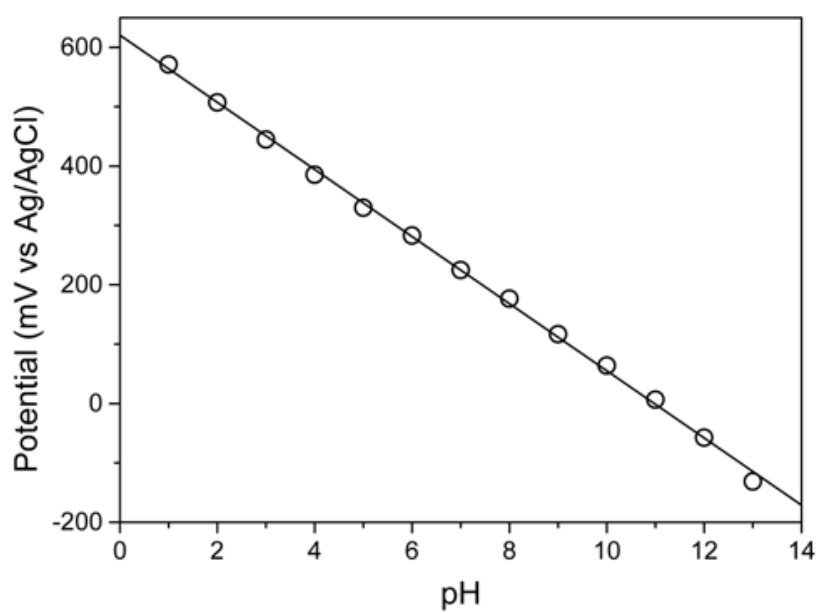

Figure 1. $\mathrm{pH}$ dependence of $\mathrm{IrO}_{2}$-modified composite electrode. The $\mathrm{pH}$ was measured against freshly prepared standard buffer solutions.

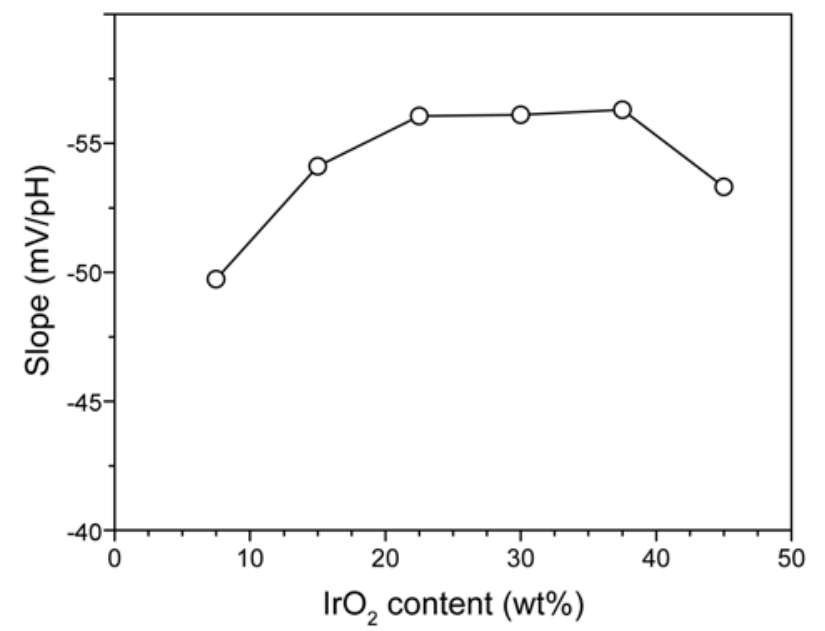

Figure 2. Effect of $\mathrm{IrO}_{2}$ content in the electrode matrix on the $\mathrm{pH}$ response of $\mathrm{IrO}_{2}$-modified composite electrode.

the oxide surface in earlier work. ${ }^{4,14}$ Accelerated aging of the surface by heating in water at elevated temperature and pressure for prompt stability was demonstrated by Katsube et al. ${ }^{15}$

The content of iridium oxide in the composite electrode matrix affected the $\mathrm{pH}$ dependence of the electrode as shown in Figure 2. The $\mathrm{pH}$ response of the electrode appeared to be higher than $50 \mathrm{mV} / \mathrm{pH}$ in most cases. The $\mathrm{pH}$ dependence increased as the iridium oxide content increased, and then leveled off between 20 to $37.5 \mathrm{wt} \%$. The physical strength of the electrodes containing iridium oxide higher than $40 \%$ was not good enough to insure the applicability of the electrode. The electrode response also became worse. The electrode containing $22.5 \mathrm{wt} \%$ of iridium oxide was selected for further evaluation of the electrochemical characteristics.

The interference characteristics of typical cations and anions were evaluated. The electrode potential in $\mathrm{pH} 7$ Tris buffer solution was measured. Then a specific amount of a salt corresponding to an ion was added and followed by 
Table 1. Effect of ions on the $\mathrm{pH}$ response of the $\mathrm{IrO}_{2}$-modified composite electrode

\begin{tabular}{|c|c|c|c|}
\hline \multirow{2}{*}{ ion } & \multirow{2}{*}{$\begin{array}{c}\text { concentration } \\
\text { tested }(\mathrm{M})\end{array}$} & \multicolumn{2}{|c|}{ electrode potential ( $v s \mathrm{Ag} / \mathrm{AgCl})$} \\
\hline & & without ion $(\mathrm{mV})$ & with ion $(\mathrm{mV})$ \\
\hline $\mathrm{Li}^{+}$ & 0.1 & 192.9 & 193.8 \\
\hline $\mathrm{Na}^{+}$ & 0.1 & 193.3 & 195.0 \\
\hline $\mathrm{K}^{+}$ & 0.1 & 193.2 & 191.3 \\
\hline $\mathrm{F}^{-}$ & 0.1 & 193.4 & 189.3 \\
\hline $\mathrm{Cl}^{-}$ & 0.1 & 192.8 & 190.8 \\
\hline $\mathrm{Br}^{-}$ & 0.1 & 192.2 & 190.6 \\
\hline$I^{-}$ & 0.1 & 192.2 & 189.0 \\
\hline $\mathrm{NH}_{4}^{+}$ & 0.01 & 193.1 & 194.0 \\
\hline $\mathrm{Mg}^{2+}$ & 0.1 & 192.4 & 189.1 \\
\hline $\mathrm{Ca}^{2+}$ & 0.1 & 191.8 & 195.0 \\
\hline $\mathrm{NO}_{3}{ }^{-}$ & 0.1 & 191.2 & 191.5 \\
\hline $\mathrm{SO}_{4}^{2-}$ & 0.1 & 193.4 & 189.7 \\
\hline $\mathrm{MoO}_{4}{ }^{2-}$ & 0.02 & 191.4 & 188.5 \\
\hline $\mathrm{Fe}(\mathrm{CN})_{6}{ }^{4-}$ & 0.01 & 192.8 & 132.4 \\
\hline $\mathrm{Fe}(\mathrm{CN})_{6}{ }^{3-}$ & 0.01 & 192.9 & 315.3 \\
\hline $\mathrm{H}_{2} \mathrm{O}_{2}$ & 0.05 & 192.5 & 255.8 \\
\hline
\end{tabular}

electrode potential measurement. Between the measurements the electrode was washed with deionized water. The test results are shown in Table 1. None of the typical ions showed any remarkable interference. However the electroactive species affected on the electrode potential dramatically as it can be seen in Table 1 . The presence of $\mathrm{Fe}(\mathrm{CN})_{6}{ }^{3-}$ and $\mathrm{H}_{2} \mathrm{O}_{2}$ shifted electrode potential positively because of their oxidizing characteristics meanwhile $\mathrm{Fe}(\mathrm{CN})_{6}{ }^{4-}$ shifted negatively. In addition the electrode was poisoned by $\mathrm{Fe}(\mathrm{CN})_{6}{ }^{3-}$ or $\mathrm{Fe}(\mathrm{CN})_{6}{ }^{4-}$. So the electrode was ground freshly between measurements for those species. It is noticeable that $\mathrm{I}^{-}$ion affected on the electrode potential remarkably in acidic condition. Similar trends for metal/metal oxide-based pH electrode were reported by others previously. ${ }^{1,16}$

Response time was defined as the time required for $90 \%$ of the final potential. In order to evaluate the response time of the $\mathrm{IrO}_{2}$ electrode, the $\mathrm{pH}$ value of test solution was stepped by quick addition of a certain amount of $\mathrm{HNO}_{3}$ solution into the test solution with a syringe. During the experiment the test solution was stirred vigorously. It took about two to twelve seconds for the $\mathrm{pH}$ change from $\mathrm{pH} 6$ to $2\left(\mathrm{t}_{90}=2 \mathrm{~s}\right.$ and $\left.\mathrm{t}_{100}=12 \mathrm{~s}\right)$. Wipf et al. reported $50 \mathrm{~ms}$ of response time for their carbon fiber-iridium oxide microelectrodes. ${ }^{7}$ Bezbaruah et al reported the response time of 1$17 \mathrm{~s}$ for acidic, neutral, and alkaline $\mathrm{pH}$ for an anodically electrodeposited iridium oxide film electrode. They found $t_{90}$ to be $\mathrm{pH}$ dependent. ${ }^{16}$

It has been known the hysteresis of iridium oxide-based electrode is somewhat large compard to the glass $\mathrm{pH}$ electrode. Marzouk et al. reported very small hysteresis of an anodically electrodeposited iridium oxide film electrode, i.e., $2.5 \pm 0.6 \mathrm{mV}^{17}$ Less hysteresis was observed for an anodically electrodeposited iridium oxide electrode. ${ }^{18}$ However, it often showed disticntive hysteresis in the case of

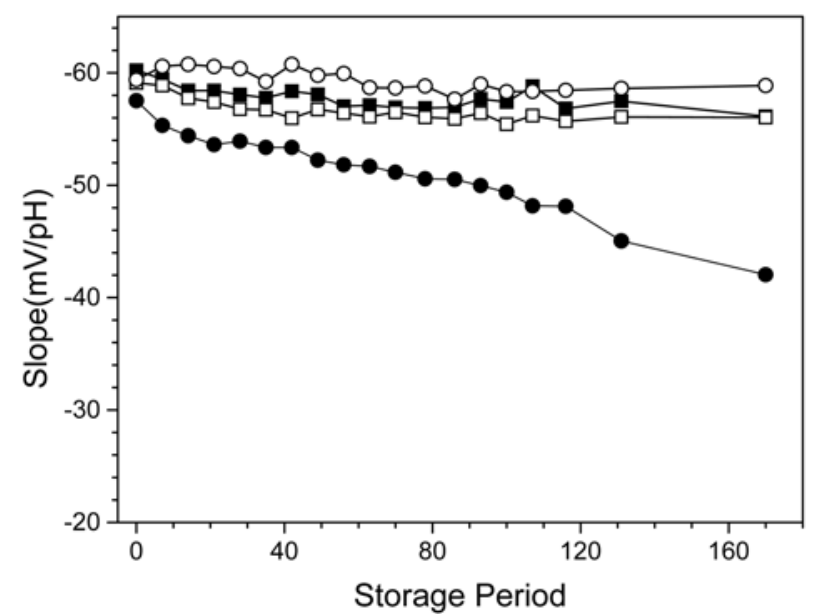

Figure 3. Effect of storage medium on the $\mathrm{pH}$ response of $\mathrm{IrO}_{2}$ modified composite electrode. Open circle: deionized water, solid circle: $4 \mathrm{M} \mathrm{KCl}$, open square: air, solid square: $\mathrm{pH} 7$ buffer.

sputtered iridium oxide film electrodes ${ }^{18}$ The hysteresis of the iridium oxide composite electrode was tested using buffers of $\mathrm{pH} \mathrm{4,} \mathrm{5,} \mathrm{7,} 9$ and 10. The electrode was calibrated five times against buffers from low $\mathrm{pH}$ to high $\mathrm{pH}$ repeatedly. A maximum drift of $5 \mathrm{mV}$ was observed which corresponds to an error of $0.1 \mathrm{pH}$ unit.

The storage medium affects on the response of the electrode. Figure 3 shows $\mathrm{pH}$ response drift depending on the storage medium. Severe drift in $\mathrm{pH}$ response was observed when the electrode was stored in $4 \mathrm{M} \mathrm{KCl}$ solution. It is likely due to slow dissolution of iridium oxide from the electrode surface by formation of chloro-iridium complex in the strong chloride solution. So chloride containing medium should be avoided to prevent deactivation of the electrode. Little drift was observed when the electrode stored in air or $\mathrm{pH}=7$ buffer solution. Long presoak time was required for normal operation when the electrode stored in air. It is not recommended for practical use. The drift of $\mathrm{pH}$ response of iridium-based $\mathrm{pH}$ electrode has been reported by others. ${ }^{14,15}$ However when the electrode was kept in deionized water between measurement the $\mathrm{pH}$ response did not drifted noticeably. This behavior is advantageous in practical aspect.

Figure 4 shows the surface renewability of the iridium oxide composite electrode. The electrode surface was ground with 2000 grit $\mathrm{SiC}$ paper and then soaked in $\mathrm{pH} 7$ buffer for 12 hours. The potential was measured against $\mathrm{pH}$ 4,7 and 10 buffers. The values of the $\mathrm{pH}$ response slope are plotted. The average slope and the relative standard deviation (RSD) appeared to be $-55.7 \mathrm{mV} / \mathrm{pH}$ and $0.7 \%$ respectively for 20 trials. The reproducible surface renewability is one of the biggest advantages because the $\mathrm{pH}$ electrode surface can be renewed by simple grinding process whenever it is contaminated or deactivated.

In conclusion a surface renewable iridium oxide-based polymeric composite $\mathrm{pH}$ electrode was developed by utilizing composite electrode technique. The electrode showed 


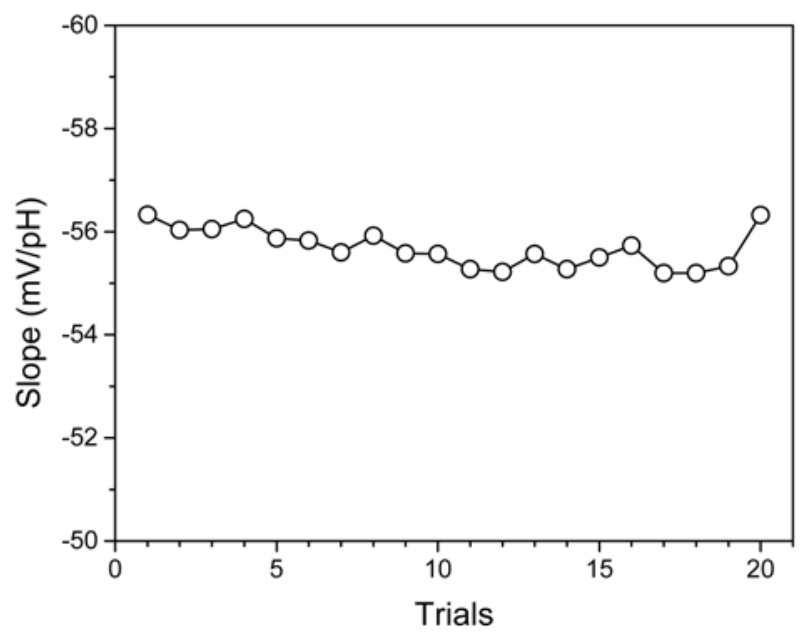

Figure 4. Graph showing the surface renewability of $\mathrm{IrO}_{2}$-modified composite electrode. The $\mathrm{pH}$ response was measured against buffer

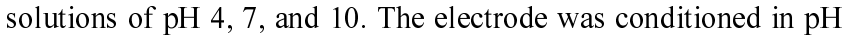
buffer solution for 12 hours after each surface renewal.

$\mathrm{pH}$ response of 50 to $60 \mathrm{mV} / \mathrm{pH}$ and very similar behaviors to the iridium oxide based $\mathrm{pH}$ electrode previously reported. The electrode response did not drifted noticeably if stored in deionized water for prolonged period. Furthermore the electrode can be ground simply to get new surface whenever contaminated or deactivated. The utility of this electrode in long-term water quality monitoring system is being examined.
Acknowledgement. This work was financially supported by Korea Research Foundation (2002-CP0252).

\section{References}

1. Fog, A.; Buck, R. P. Sens. Actuators 1984, 5, 137.

2. Glab, S.; Hulanicki, A.; Edwall, G.; Ingman, F. Crit. Rev. Anal. Chem. 1989, 21, 29.

3. VanHoudt, P.; Lewandowski, Z.; Little, B. Biotech. Bioeng. 1992, $40,601$.

4. Kinoshita, K.; Madou, M. J. J. Electrochem. Soc. 1984, 131, 1089.

5. Grant, S. A.; Bettencourt, K.; Krulevitch, P.; Hamilton, J.; Glass, R. Crit. Review Biomed. Eng. 2000, 28, 159.

6. Wang, M.; Yao, S.; Madou, M. Sens. Actuators B 2002, 81, 313.

7. Wipf, D. O.; Ge, F.; Spaine, T. W.; Baur, J. E. Anal. Chem. 2000, $72,4921$.

8. Shaw, B. R.; Creasy, K. E. J. Electroanal. Chem. 1988, 243, 209.

9. Seo, K.; Kim, S.; Park, J. Anal. Chem. 1998, 70, 2936.

10. CRC Handbook of Chemistry and Physics, $83^{\text {rd }}$ ed.; Lide, D. R. Ed.; CRC Press: NY, USA, 2002-2003.

11. Hara, M.; Lean, J. T.; Mallouk, T. E. Chem. Mater. 2001, 13, 4668.

12. Burke, L. D.; Whelan, D. P. J. Electroanal. Chem. 1984, 162, 121.

13. Burke, L. D.; Mulcahy, J. K.; Whelan, D. P. J. Electroanal. Chem. 1984, 163, 117.

14. Kreider, K. G.; Tarlov, M. J.; Cline, J. P. Sens. Actuators B 1995, 28, 167.

15. Katsube, T.; Lauks, I.; Zemel, J. N. Sens. Actuators 1982, 2, 399.

16. Bezbaruah, A. N.; Zhang, T. C. Anal. Chem. 2002, 74, 5726.

17. Marzouk, S. A. M.; Ufer, S.; Buck, R. P.; Johson, T. A.; Dunlap, L. A.; Cascio, W. E. Anal. Chem. 1998, 70, 5054.

18. Tarlov, M. J.; Semancik, S.; Kreider, K. G. Sens. Actuators B 1990, 1, 293. 